\title{
Antioxidant, antimicrobial activity and phytochemical analysis of the seeds extract of Cucumis sativus Linn
}

\author{
Hussan Ara Begum ${ }^{1 *}$, Fayaz Asad ${ }^{2}$, Abdul Sadiq ${ }^{3}$, Shujaul Mulk ${ }^{4}$ and \\ Kishwar Ali ${ }^{5}$ \\ 1. Department of Botany, Abdul Wali Khan University Mardan, KPK-Pakistan \\ 2. Department of Botany, Bacha Khan University Charsadda, KPK-Pakistan \\ 3. Department of Pharmacy, University of Malakand, KPK-Pakistan \\ 4. Department of Botany, Quid e azam University Isalmabad-Pakiatan \\ 5. Department of Botany, University of Malakand, KPK-Pakistan \\ *Corresponding author's email: hussanara.begum@gmail.com \\ Citation
}

Hussan Ara Begum, Fayaz Asad, Abdul Sadiq, Shujaul Mulk and Kishwar Ali. Antioxidant, antimicrobial activity and phytochemical analysis of the seeds extract of Cucumis sativus Linn. Pure and Applied Biology. Vol. 8, Issue 1, pp433-441. http://dx.doi.org/10.19045/bspab.2018.700202

\begin{tabular}{llll}
\hline \hline Received: 27/10/2018 & Revised: 29/11/2018 & Accepted: 30/11/2018 & Online First: 04/12/2018 \\
\hline \hline
\end{tabular}

\section{Abstract}

The prehistoric interaction of plants and human is being strengthened by the remarkable use of plants as remedy against diseases. Cucumis sativus L. is extensively cultivated globally including Pakistan. The present study was carried out to find the antioxidant, antimicrobial and phytochemical analysis of Cucumis sativus seed extract. Phytochemical analysis of ethanolic extract revealed the presence of flavonoids, terpenoids, tannins, cardiac glycoside, phenols and carbohydrates. 2,2-diphenyl-1-picrylhydrazyl (DPPH) method was used for antioxidant activity. Crude ethanolic extract showed maximum DPPH scavenging activity of $46.05 \pm 1.23$ at $500 \mu \mathrm{g} / \mathrm{ml}$, while ascorbic acid showed $92.5 \%$. For Antimicrobial activity against selected bacteria and fungi by agar well diffusion method was used. In the antibacterial activity, crude ethanolic extract was most active against Staphylococcus aureus $(21.5 \mathrm{~mm})$ and less against Shigella flexneri $(17.0 \mathrm{~mm})$. The $\mathrm{n}$-haxane fraction was highly active against Salmonella typhi $(26 \mathrm{~mm})$, DCM against E. coli $(16.25 \mathrm{~mm})$ and Salmonella typhi showed $16.0 \mathrm{~mm}$ inhibition with ethyl acetate. Crude extract of ethanol was tested against Alternaria, Acremonium, Verticellium, Pythium and Tricoderma sps. Alternaria showed low zone of inhibition $(08 \mathrm{~mm})$ while the rest of fungi were highly susceptible with zone of inhibition $15 \mathrm{~mm}, 14 \mathrm{~mm}, 17 \mathrm{~mm}$ and $15 \mathrm{~mm}$ respectively. The Pythium spp. was highly susceptible to nhaxane fraction $(20.00 \mathrm{~mm})$, Acremonium to DCM fraction $(20.00 \mathrm{~mm})$ and to ethyl acetate $(16.00 \mathrm{~mm})$. The results showed significant antimicrobial and antioxidant activity which might be because of flavonoids, terpenoids, tannins and phenols in there, suggesting that $C$. sativus should be used as an active nutrition to control microbial infections leading to chronic diseases.

Keywords: Antimicrobial activity; Antioxidant activity; Cucumis sativus L.; Phytochemical analysis

\section{Introduction}

Plants are basic therapy springs for diseases that can be traced back to time immemorial. Having little or no harm effects of plant materials, therefore herbs based medicines flourished now a days. Plants possess specific biochemical components which exerts curative effects on living organism to treat 
various diseases. [1]. The concrete significance of the medicinal plants is because of antioxidants and antimicrobials properties [2, 3]. Microbes become resistant to the available sources of drugs, novel plant sources are needed to handle these resistant strains. It is needed to comprehend the genetics of the resistant microbes for developing new drugs better than the existing ones to reduce threat of infectious diseases. . Plant sources possess chemicals like alkaloids, glycosides, flavonoids, terpenoids etc. in plenty which are potential sources of biological porperties [4]. There is an inborn antioxidative mechanism in the human body and many natural activities such as the anticarcinogenic and anti-aging responses, initiate due to antioxidants. Antioxidants soothes or disable free radicals, earlier their attack to the target cells. Disease occurred due to production of free radicals in living system which damage it causing serious and long lasting diseases like diabetes, ageing, low immune system neuro-degeneration etc. The diseased body needed antioxidants in the form of proper nutritional and medicinal supplements to overcome the threat. Plant based research showed that antioxidants are there in the form of chemical components like phenols, flavonoids, proanthocynidine etc. Plants based antioxidants enhances the defense against diseases and slows down the aging process. Natural antioxidants reduces the risks of infectious and chronic diseases [5]. Medicinal plants are continuously investigated for the therapeutic properties especially for antioxidants. Natural antioxidants either in fresh form or its pure chemical ingredients are active to check the critical progressions produced by reactive oxygen species (ROS) [6]. Plants are best sources of human therapy due to its phytochemicals present there, these have resisting potential against diseases. Antiinflammatory, anticancer, anti-malarial, inhibiting cholesterol production, antiviral and antibacterial bioassays are important pharmacological activities of terpenoids. Alkaloids are sedatives and are mostly plants derivatives phytochemicals like alkaloids are anesthetics, terpenoids are anti-inflammatory anticanereous, anti-malarial, inhibiting cholesterol formataion and anti-microbial. These all are obtained from plat sources [7]. The Cucumis is an annual climbing plant and about $15-30 \mathrm{~cm}$ with large lamina covering the fruit. The Cucumis sativus (Cucurbitaceae) fruit is edible. The fruit possesses numerous activities such as antihyperglycemic activity [8], inhibitory effects on protein Kinase C (PKC) activity [9], anti-oxidant activity [10-12], amyl-lytic activity [13], anticancer activity [14], anticlastogenic activity [15], and anti-mutagenic activity $[16,17]$. Cucumis sativus is used in raw form fresh. Its fruit extract possess antioxidant and analgesic activity [18], used as carminative and antacid [19]. Studies showed antioxidant and anti-ulcer effects [20] Seeds are good sources of protein, fat, minerals and calcium [21]. Deficiency of antioxidants can be replaced by using fresh Cucumis [22, 23]. The only harmless substitute to internal antioxidants is fresh Fruits, vegetables and similar foodstuff. For preserving the normal cell activities. Fruits and vegetables offer defense against longlasting illnesses like cancer and cardiovascular disorder due to the presence of antioxidants especially, vitamins, phenolic and flavonoids, coumarin, tannins and stilbenes [24]. Due to marvelous prospective of the components against prolonged diseases, various researches have proved the energetic character of fruits and vegetables as antioxidants to preserve physique utility in regular manner [25]. The purpose of the present project was to explore the underlying curative potentials of the plant in the form of antioxidant, antibacterial, antifungal and preliminarily phytochemical screening of seeds of Cucumis sativus. 


\section{Materials and methods Plant Collection}

Fresh seeds of Cucumis sativus were collected from ripened dried fruit of the plant. These were properly dried and seed coats were removed from all seeds carefully. Dried seeds were grounded with the help of pistil and mortar to get powdered material.

Preparation of crude extract and its fractions

Extraction is the process in which desired plant tissues will be soaked in solvent for a certain time period, from which medicinally active principles are dissolved in the solvent

Table 1. Amount of different extracts of seeds of Cucumis sativus Linn

\begin{tabular}{|c|c|c|c|c|}
\hline Grounded material & $\begin{array}{c}\text { Ethanolic } \\
\text { extract }\end{array}$ & $\begin{array}{c}\text { n-hexane } \\
\text { fractions }\end{array}$ & $\begin{array}{c}\text { DCM } \\
\text { fraction }\end{array}$ & Ethyl acetate fraction \\
\hline $1 \mathrm{~kg}$ & $26 \mathrm{~g}$ & $7 \mathrm{~g}$ & $3 \mathrm{~g}$ & $3 \mathrm{~g}$ \\
\hline
\end{tabular}

\section{Preparation of media}

\section{Preparing the growth-media}

Required bacterial broth was dissolved in distilled water to prepare media for bacterial growth. $\mathrm{pH}$ was attuned as at 7.0-6.8 and autoclaved. Strains were injected and incubated at $37^{\circ} \mathrm{C}$ for one day. Bacterial Nutrient agar was dissolved in distilled water (for bioassay in petripaltes) and autoclaved.

Selected Strains: Pseudomonas aeruginosa, Shigella flexneri, Salmonella typhi, Escherichia coli and Staphylococcus aurous

Inoculation: from one day old bacterial broth, inoculum was selected to be used in agar poured in petriplates for activity after getting the McFarland Turbidity Standard. Bacteria from 24-hour old culture in LB broth (Miller) of selected bacterial strains were mixed with physiological normal saline solution until a McFarland turbidity standard $\left[10^{6}\right.$ colony forming unit (CFU) $\left.\mathrm{ml}^{-1}\right]$ was obtained. Then this inoculum was used to seed LB Agar Medium.

Autoclaved media was left to solidify in petriplates at room temperature. Agar well diffusion technique [26] was used. Agar plates were covered with the selected strains leaving undissolved materials. In this study $70 \%$ ethanol were used for extraction. The grounded material was soaked in $70 \%$ ethanol and kept at room temperature for 3-7 days. Filtrate was collected and was concentrated with the help of rotary evaporator. The concentrated crude extract was like a gum. This was the crude ethanolic extract and further fractionation was carried out, subjecting the crude sample to extraction with n-hexane, Dichloromethane and ethyl acetate respectively on polarity bases (Table $1)$. by using a sterile cotton-swab then wells were made with help of a sterile cork borer.

\section{Extract Concentration}

$20 \mathrm{mg}$ of dried or partially dried extract was liquefied in $1 \mathrm{ml}$ of dimethylsulfoxide (DMSO).

\section{Zone of inhibition}

$75 \mu \mathrm{l}$ of each extract was used into the wells with the help of a sterile micropipette and plates were incubated for one day at $37^{\circ} \mathrm{C}$ to find out the inhibition zone. Diameter of inhibiting zones were calculated all-around the wells. Activity was repeated three times and mean value with standard error was calculated by DMRT (Duncan multiple range test) through SPSS.

\section{Fungal strains used}

Alternaria, Acremonium, Verticellium, Pythium and Tricoderma were used for antifungal assessment.

\section{Media preparation for fungal growth}

PDA potato dextrose agar prepared in sterile water was used for culturing fungi, autoclaved and poured into autoclaved petriplates. Kept at room temperature to solidify. 


\section{Agar -well method}

Method described by Samie et al. [27] was used for activity. Using the micropipette, $100 \mu 1$ of different fungal cultures were spread over the agar plates with the help of inoculating loop in double distil water. Using a sterile cork borer, hole) were made in each of the culture plates. $75 \mu \mathrm{l}$ of crude and different fractions of Cucumis sativus extract was poured added and inoculated plates were incubated at $28^{\circ} \mathrm{C}$ for one day or two day showing clear inhibitions. Inhibiting zones were calculated in millimeter, indicating the activity. Each test was triplicated and standard deviation was calculated.

\section{Preliminary phytochemical tests}

Various phytochemical methods $[22,29,30$, 36] were used to screen the crude extract of $C$. sativus seeds.

Antioxidant assay: Scavenging activity of free radicals

Antioxidant assay of seeds of Cucumis sativus was calculated using 1, 1-diphenyl2-picryl hydrazyl (DPPH) assay following the method of Ahmad and Patel \& Patel [31, 32]. $0.1 \mathrm{mM}$ concentration of $\mathrm{DPPH}$ in methanol was arranged. $1 \mathrm{ml}$ of this concentration was used in $3 \mathrm{ml}$ of crude extract to different concentration $(250$ \& $500 \mu \mathrm{g} / \mathrm{ml}$ ). This mixture was shaken briskly and stand at room temperature for 30 minutes. Then by using spectrophotometer, absorbance was calculated at $517 \mathrm{~nm}$. Ascorbic acid was used as standard. The percent DPPH was measured by using the following equation:

DPPH scavenging effect (\%) or Percent inhibition $=\mathrm{A}_{0}-\mathrm{A}_{1} / \mathrm{A}_{0} \times 100$.

Where $\mathrm{A}_{0}$ was the Absorbance of control reaction and $A_{1}$ was the Absorbance in the presence of the test or standard sample [33].

\section{Results and discussion}

Antimicrobial activity of the crude ethanolic extract and three fractions n-hexane, dichloromethane and ethyl acetate were studied against five bacterial and five fungal strains. Extracts showed potent activity against all the microorganisms.

Antimicrobial potential was assessed by recording the zone of inhibition of the microbial growth in $\mathrm{mm}$. The (Table 2) showed antibacterial activity and (Table 3 ) shows antifungal activity. It is reported that medicinal plants can be good sources of antibacterial agents [34]. In the antibacterial activity, the crude extract was the most active against Escherichia coli, Staphylococcus aurous $(22.5 \mathrm{~mm})$ and less against Shigella flexneri $(17.0 \mathrm{~mm})$. The $\mathrm{n}$-hexane fraction was the most active against Salmonella typhi (26.0mm), DCM was $16.25 \mathrm{~mm}$ against Escherichia coli and Salmonella typhi showed $16.0 \mathrm{~mm}$ zone of inhibition with ethyl acetate fraction. Similarly ethanol and methanol extracts of $P$. emblica reduces the growth of bacteria [35]. The bacterial organism were susceptible to medicinal plant extracts. It is reported that as compared to gram positive, gram negative bacterial strains are very vulnerable to plant extracts $[36,37]$. In antifungal activity the crude ethanolic extract was tested against Alternaria, Acremonium, Verticellium, Pythium and Tricoderma sps. Alternaria showed less zone of inhibition $(08 \mathrm{~mm})$ while the rest of the fungal pathogens showed susceptibility with the zone of inhibition of $15 \mathrm{~mm}, 14 \mathrm{~mm}$, $17 \mathrm{~mm}$, and $15 \mathrm{~mm}$ against Acremonium, Verticellium, Pythium and Tricoderma respectively. The Pythium sps. was highly susceptible to n-hexane fraction showing $20.00 \mathrm{~mm}$, Acremonium to DCM fraction with $20.00 \mathrm{~mm}$ and to ethyl acetate showing $16.00 \mathrm{~mm}$ zone of inhibition. Candida albicans showed resistance to various extract of medicinal plants of western Himalayas [38]. Fungi were also found susceptible to the extracts and fractions of Cucumis sativus. It is reported that the fungus Phytium was specifically inhibited, recorded in various reports [39-42]. 
The microbic susceptibility to different extract of the seeds of Cucumis sativus, expresses its anti-infection ability. All the solvent extracts of the seeds of $C$. sativus was found active against the tested organisms, which indicated the presence of broad spectrum antibiotic compounds. These extracts also showed active potentials against tested fungus which revealed the presence of potent antimicrobial constituents in all the solvent extracts. Regular intake of this fruit may decrease the possibilities of infections. Preliminary phytochemical analysis showed (Table 4) the presence of Alkaloids, Flavonoids, Terpenoids, Tannin, Cardiac glycosides, phenols and Carbohydrates. The ethanolic extracts of seeds of $C$. sativus was screened for different Phytochemicals like anthraquinones, alkaloids, steroids, tannin, terpenoid, flavonoids, saponin and cardiac glycosides. The presence of flavonoids, cardiac glycosides, tannin and saponin as shown in (Table 4), explain its dietary and therapeutic significance. The present study is in accordance with the previous work and the slight change may be because of soil mineral composition, cultivation and climatic differences [18, 43-45].
Antioxidants help to protect living system from being damage. Fruits, vegetables and other wild plants are good sources of these antioxidants $[46,47]$. In vitro, free radical scavenging effects of $C$. sativus was evaluated by DPPH method, ascorbic acid was used as standard and a spectrophotometer was uses at $517 \mathrm{~nm}$. The results showed (Table 5) that at $125 \mu \mathrm{g} / \mathrm{ml}$ conc. the effect was $28.1 \%, 250 \mu \mathrm{g} / \mathrm{ml}$ concentration the effect was $32.0 \%$ and at $500 \mu \mathrm{g} / \mathrm{ml}$, it was $46.05 \%$. So, the extract showed having a clear effect on scavenging the free radicals. Free radicals are said to be actively involved in many chronic diseases, such as cardiac and cancer among others [18]. The antioxidants, hunt the free radicals which formed in living organisms. The antioxidative ability of natural products has been extensively studied by DPPH test. From the preliminary phytochemical screening of the seeds ethanolic extract of Cucumis sativus showed to consist of glycosides, steroids, carbohydrates, saponin and tannins, it is concluded that, the occurrence of flavonoids \& tannins in the extract proposes that these complexes might be responsible for scavenging free radicals and said to be as an effective antioxidant $[48,49]$.

Table 2. Antibacterial activity of seeds of Cucumis sativus Linn. Zone of inhibition in mm, concentration in $\mu / \mathrm{ml}$

\begin{tabular}{|c|c|c|c|c|c|}
\hline Sample & $\begin{array}{c}\text { Staphylococcus } \\
\text { aurous }\end{array}$ & $\begin{array}{c}\text { Shigella } \\
\text { flexneri }\end{array}$ & $\begin{array}{c}\text { Pseudomonas } \\
\text { aeruginosa }\end{array}$ & $\begin{array}{c}\text { Escherichia } \\
\text { coli }\end{array}$ & $\begin{array}{c}\text { Salmonella } \\
\text { typhi }\end{array}$ \\
\hline $\begin{array}{c}\text { Crude ethanolic } \\
\text { extract }\end{array}$ & $21.5 \pm 0.02$ & $17.0 \pm 0.22$ & $20.9 \pm 0.03$ & $22.5 \pm 0.06$ & $20.0 \pm 0.31$ \\
\hline n-hexane & $19.0 \pm 0.21$ & $10.0 \pm 0.03$ & $09.2 \pm 0.21$ & $18.25 \pm 0.11$ & $26.0 \pm 0.19$ \\
\hline DCM & $10.15 \pm 0.12$ & $12.0 \pm 0.19$ & $07.15 \pm 0.14$ & $16.25 \pm 0.15$ & $14.5 \pm 0.14$ \\
\hline Ethyl acetate & $11.5 \pm 0.11$ & $13 \pm 0.09$ & $07.5 \pm 0.12$ & $14.5 \pm 0.13$ & $16.0 \pm 0.15$ \\
\hline
\end{tabular}

Average of triplicate

Table 3. Antifungal activity of seeds of Cucumis sativus Linn. Zone of inhibition in mm, concentration in $\mu / \mathbf{m l}$

\begin{tabular}{|c|c|c|c|c|c|}
\hline Sample & Alternaria & Acremonium & Verticellium & Pythium & Trichoderma \\
\hline $\begin{array}{c}\text { Crude ethanolic } \\
\text { extract }\end{array}$ & $8.0 \pm 0.12$ & $15.0 \pm 0.19$ & $1.04 \pm 0.15$ & $17.0 \pm 0.21$ & $15.0 \pm 0.21$ \\
\hline n-hexane & $6.0 \pm 0.19$ & $14.0 \pm 0.12$ & $11.0 \pm 0.09$ & $20.0 \pm 0.09$ & $14.0 \pm 0.13$ \\
\hline DCM & $7.0 \pm 0.19$ & 20.00 .09 & $14.5 \pm 0.08$ & $10.5 \pm 0.16$ & $14.5 \pm 0.09$ \\
\hline Ethyl acetate & $7.0 \pm 0.11$ & $16.0 \pm 0.09$ & $13.0 \pm 0.12$ & $8.5 \pm 0.02$ & $8.5 \pm 0.12$ \\
\hline
\end{tabular}

Average of triplicate 
Table 4. Preliminary phytochemical tests Cucumis sativus Linn

\begin{tabular}{|c|c|}
\hline Botanical name & Cucumis sativus \\
\hline Parts used & seeds \\
\hline Alkaloids & - \\
\hline Flavonoids & + \\
\hline Terpenoids & + \\
\hline Tannin & + \\
\hline Anthraquinones & - \\
\hline Cardiac glycosides & + \\
\hline phenols & + \\
\hline Carbohydrates & + \\
\hline Saponin & - \\
\hline
\end{tabular}

Table 5. Antioxidant activity of seeds of Cucumis sativus Linn

\begin{tabular}{|c|c|c|}
\hline & Conc. $(\boldsymbol{\mu g} / \mathbf{m l})$ & Inhibition \%age \\
\hline Crude ethanolic extract & 500 & $46.05 \pm 1.23$ \\
\hline & 250 & $32.0 \pm 1.01$ \\
\hline & 125 & $28.1 \pm 1.0$ \\
\hline & 500 & $92.55 \pm 2.50$ \\
\hline Ascorbic acid & 250 & $62.33 \pm 0.22$ \\
\hline & 125 & $45.2 \pm 1.0$ \\
\hline
\end{tabular}

Average of triplicate

\section{Conclusion}

The present study suggests that the use of plant Cucumis sativus is very beneficial in terms of enhancing immune system of the living organisms and can be good source of isolating novel drugs to improve human health.

\section{Authors' contributions}

Experimental design and lab facility, analyze data and wrote the paper: HA Begum, Lab work and help in writing the paper: F Asad, Analyze the data: A Sadiq, Help in paper writing: S Mulk, Help in data analysis: K Ali.

\section{References}

1. Edeoga HO, Okwu DE \& Mbaebie BO (2005). Phytochemical constituents of some Nigerian medicinal plants. African J of Biotechnol 4(7): 685-688.

2. Kubola J. \& Siriamornpun S (2008). Phenolic contents and antioxidant activities of bitter gourd (Momordica charantia $\mathrm{L}$.) leaf, stem and fruit fraction extracts in vitro. Food Chem 110(4): 881-890.
3. Wang S, Melnyk JP, Tsao R \& Marcone MF (2011). Food Res Inter 44: 14.

4. Dahanukar SA, Kulkarni RA \& Rege NN (2000). Pharmacology of medicinal plants and natural products. Indian $J$ Pharmacol 32: 81-118.

5. Saeed T, Khan MR \& Shabbir M (2012). Antioxidant activity, total phenolic and total flavonoid contents of whole plant extracts Torilis leptophylla L. BMC Comple and Alter Med 12: 221.

6. Zengin G, Cakmak YS, Guler GO \& Aktumsek A (2011). Antioxidant properties of methanolic extract and fatty acid composition of Centaurea urvillei DC. Subsp. hayekiana Wagenitz. Res Nat Prod 5:123-132.

7. Wadood A, Ghufran M, Jamal SB, Naeem M, Khan A \& Ghaffar R (2013). Phytochemical analysis of medicinal plants occurring in local area of Mardan. Biochem Anal 2(4): 1-4.

8. Roman-Ramos R, Flores-Saenz JL \& Alarcon-Aguilar FJ (1995). Anti- 
hyperglycemic effect of some edible plants. J of Ethnopharmacol 48(1): 2532.

9. Sudheesh S \& Vijayalakshmi NR (2007). Role of pectin from cucumber (Cucumis sativus) in modulation of protein kinase $\mathrm{C}$ activity and regulation of glycogen metabolism in rats. Indian $J$ Biochem Biophys 44(3): 183-5.

10. Stratil P, Klejdus BI \& Kuban V (2006). Determination of total content of phenolic compounds and their antioxidant activity in vegetables evaluation of spectrophotometric methods. Agric Food Chem 54: 616-607.

11. Chu YF, Sun J, Wu X \& Liu RH (2002). Antioxidant and antiproliferative activities of common vegetables. J Agric Food Chem 50(23): 6910-6.

12. Pellegrini N, Serafini M, Colombi B, Del Rio D, Salvatore S, Bianchi M \& Brighenti F (2003). Total Antioxidant Capacity of Plant Foods, Beverages and Oils Consumed in Italy Assessed by three different In Vitro Assays. J Nutr 133: 2812- 2819.

13. Repka V \& Fischerová I (1999). Induction and distribution of amylolytic activity in Cucumis sativus. In response to virus infection. Acta Virologic 43(4): 227-35.

14. Villasenor IM, Simon MK \& Villanueva AM (2002). Comparative potencies of nutraceuticals in chemically induced skin tumor prevention. Nutr Cancer 44(1): 66-70.

15. Edenharder R, Frangart J, Hager $M$, Hofmann P \& Rauscher R (1998). Protective effects of fruits and vegetables against in vivo clastogenicity of cyclophosphamide or benzo[a]pyrene in mice. Food Chem Toxicol 36: 637645.

16. Edenharder R, Kurz P, John K, Burgard S \& Seeger K (1994). In vitro effect of vegetable and fruit juices on the mutagenicity of 2- amino-3methylimidazo[4,5-f]quinoline, 2amino-3,4-dimethylimidazo [4,5-f] quinoline and 2-amino-3,8dimethylimidazo [4,5-f] quinoxaline. Food Chem Toxicol 32(5): 443-59.

17. Zhao ZZ \& Huang MT (1992). A SOS induction test screening study for vegetables inhibiting mutagenicity caused by antineoplastic drugs. Zhonghua yu fang yi xue za zhi; Chinese J of Preven Med 26(2): 92-93.

18. Kumar D, Kumar S, Singh J, Narender, Rashmi, Vashistha BD \& Singh N (2010). Free radical scavenging and analgesic activities of Cucumis sativus L. fruit extract. J of Young Pharmacist 2(4): 365-368.

19. Sharma S, Dwivedi J \& Paliwal S (2012). Evaluation of antacid and carminative properties of Cucumis sativus under simulated conditions. Scholars Res Library, Der Pharmacia Lettre 4(1): 234-239.

20. Gill NS, Garg M, Bansal R, Sood S, Muthuraman A, Bali M \& Sharma PD (2009). Evaluation of antioxidant and antiulcer potential of Cucumis sativus L. seed extract in rats. Asian $J$ of Clinical Nutr 1(3): 131- 138.

21. Abiodun OA \&Adeleke RO (2010). Comparative studies on nutritional composition of four melon seeds varieties. Pak J of Nutr 9(9): 905-908.

22. Madhavi DL \& Salunkhe DK (1995).Toxicological Aspects of Food Antioxidants. Food Antioxidants, Eds. Dekker: New York pp 267.

23. Singh RP, Chidambara Murthy KN \& Jayaprakasha GK (2002). Studies on the antioxidant activity of pomegranate (Punica granatum) peel and seed extracts using in vitro models. J of Agric and Food Chem 50(1): 81-86.

24. Cao G, Sofic E \& Prior RL (1996). Antioxidant capacity of tea and common 
vegetables. $J$ of Agric and Food Chem 44(11): 3426-3431.

25. Song W, Derito CM, Liu MK, He X, Dong M \& Liu RH (2010). Cellular antioxidant activity of common vegetables. Journal of Agric and Food Chem 58(11): 6621-6629.

26. Perez C, Pauli M \& Bazerque P (1990). An antibiotic assay by agar-well diffusion method. Acta Biologiae ET Medecine Experimentaalis 15: 113-115.

27. Samie A, Tambani T, Harshfield E, Green E, Ramalivhana JE \& Bessong PO (2010). Antifungal Activities of selected Venda medicinal plants against Candida albicans, Candida krusei and Cryptococcus neoformans isolated from South African AIDS patients. African J of Biotechnol 2965-2976.

28. Deshpande SN \& Kadam DG (2013). Preliminary phytochemical analysis of some medicinal plants. DAV Inter $J$ of Sci 2(2): 61-65.

29. Evans WC (2002). Trease and Evan's pharmacognosy. 5th ed., Harcourt brace and company pp 336.

30. Iyengar MA (1995). Study of crude drugs. 8th ed., Manipal power press, Manipal, India pp 2.

31. Ahmed M, Saeed F, Mehjabeen, \& NoorJahan (2013). Evaluation of Insecticidal and Antioxidant activity of selected Medicinal plants. $J$ of Pharmacog \& Phytochem 2(3): 153-158.

32. Patel RM \& Patel NJ (2011). In vitro antioxidant activity of coumarin compounds by DPPH, superoxide and nitric oxide free radical scavenging methods. $J$ of Adv Pharm Edu \& Res 1: 52-68.

33. Achola KJ \& munenge RW (1998). Bronchodilating and uterine activities of Ageratum conyzoides extract. Pharmaceutical Biol 36(2): 93-96

34. Mousavi SM, Bagheri G \& Saeidi S (2015). Antibacterial activities of the hydroalcoholic extract of portulaca oleracea leaves and seeds in sistan region, Southeastern Iran. Inter $J$ of Infection 2(2).

35. Selvamohan T, Ramadas V \& Kishore SSS (2012). Antimicrobial activity of selected medicinal plants against some selected human pathogenic bacteria. $A d v$ in Appl Sci Res 3(5): 3374-3381.

36. Nostro A, Germano M, D'angelo V, Marino A \& Cannatelli M (2000). Extraction methods and bioautography for evaluation of medicinal plant antimicrobial activity. Letters in Appl Microbiol 30(5): 379-384.

37. Ojala T, Remes S, Haansuu P, Vuorela $\mathrm{H}$, Hiltunen R, Haahtela K \& Vuorela P (2000). Antimicrobial activity of some coumarin containing herbal plants growing in Finland. $J$ of Ethnopharmacol 73(1-2): 299-305.

38. Uniyal SK, Singh KN, Jamwal P \& Lal B (2006). Traditional use of medicinal plants among the local communities of Chhota Bhangal, Western Himalayan. $J$ of Ethno Biol and Ethnomedicine 2: 14.

39. Haouala R, Hawala S, El-Ayeb A, Khanfir R \& Boughanmi N (2006). Aqueous and organic extracts of Trigonella foenum-graecum L. inhibit the mycelia growth of fungi. J of Environ Sci 20(12): 1453-1457.

40. Švecová E, Colla G \& Crinò P (2016). Antifungal activity of Boerhavia diffusa L. extract against Phytophthora spp. in tomato and pepper. European J of Plant Pathology 1-8.

41. Mezaache-Aichour S, Guechi A, Nicklin J, Drider D, Prevost H \& Strange RN (2012). Isolation, identification and antimicrobial activity of pseudomonads isolated from the rhizosphere of potatoes growing in Algeria. $J$ of Plant Pathol 94(1): 89-98.

42. Du S, Lu H, Yang D, Li H, Gu X, Wan C, Jia C, Wang M, Li X \& Qin Z (2015). 
Synthesis, Antifungal Activity and QSAR of Some Novel Carboxylic Acid Amides. Mol 20: 4071-4087.

43. Arabshahi-Delouee S \& Urooj A (2007). Antioxidant properties of various solvent extracts of mulberry (Morus indica L.) leaves. Food Chem 102(4): 1233-1240.

44. Doughari JH, Elmahmood AM \& Manzara S (2007). Studies on the antibacterial activity of root extracts of Carica papaya L. African J of Microbiol Res 1(3): 37-41.

45. Sofowara AE (1993). Medicinal plants and traditional medicine in Africa. Spectrum books 1td, Ibadan 2: 288.

46. Decker M, Kraus B \& Heilmann J (2008). Design, synthesis and pharmacological evaluation of hybrid molecules out of quinazolinimines and lipoic acid lead to highly potent and selective butyrylcholinesterase inhibitors with antioxidant properties. Bioorg \& Medicinal Chem 16(8): 4252-4261.

47. Youdim KA, Shukitt-Hale B \& Joseph JA (2004). Flavonoids and the brain: interactions at the blood-brain barrier and their physiological effects on the central nervous system. Free Radical Biol and Med 37(11): 1683-1693.

48. Chen JH \& Ho CT (1997). Antioxidant activities of caffeic acid and its related hydroxycinnamic acid. J Agric Food Chem 45: 2374-2378.

49. Rubio L, Motilva MJ \& Romero MP (2013). Recent advances in biologically active compounds in herbs and spices: a review of the most effective antioxidant and anti-inflammatory active principles. Crit Rev Food Sci Nutr 53: 943-953. 